\title{
原著
}

\author{
歯周病におけるプロービングデプス，アタッチメントレベルの \\ 臨床的意義に関する研究 \\ 友藤孝明*1 東 哲司*1 草野弘揮*1 山本龍生*1 \\ 多田 徹*2 森田学*3 渡邊 達夫*1 \\ *1岡山大学大学院医歯学総合研究科 社会環境生命科学専攻 \\ 長寿社会医学講座 口腔保健学分野 \\ *2パートナーズ・クリニック伊島 \\ ${ }^{*}$ 北海道大学大学院歯学研究科 口腔健康科学講座
}

(2004 年 10 月 2 日受理)

\section{Role of Measurements of Probing Depth and Attachment Level in Periodontal Patients}

\author{
Takaaki Tomofuji*1, Tetsuji Azuma*1, Hiroki Kusano*1, Tatsuo Yamamoto*1, \\ Toru Tada*2, Manabu Morita*3 and Tatsuo Watanabe*1 \\ ${ }^{* 1}$ Department of Oral Health, Longevity and Social Medicine, \\ Social and Environmental Sciences, \\ Okayama University Graduate School of Medicine and Dentistry \\ *2Partners Clinic Ishima \\ ${ }^{* 3}$ Department of Oral Health Science, Hokkaido University Graduate \\ School of Dental Medicine \\ Accepted for publication 2 October 2004
}

Probing depth (PD) and attachment level (AL) are often used as clinical indices. The purpose of this study was to evaluate the clinical relevance of PD and AL to identify periodontal conditions (e.g., active or non-active) in patients. One hundred and ninety-three periodontal patients (Mean age ; 61.7 years old, 77 males and 116 females) participated in this study. They were selected as those who had exhibited no clinical signs of recurrent periodontitis for at least 6 months prior to the study. PD and AL assessed at 6 sites around each tooth were analyzed for the relationship with age, gender, bleeding on probing (BOP) and tooth mobility. The mean PD and AL per person were $1.89 \mathrm{~mm}$ and $2.75 \mathrm{~mm}$, respectively. The AL per person increased significantly according to age $(r=0.36, p<0.001)$, whereas no significant correlation was observed between the mean PD and age. There were significant differences of the mean PD and AL ( $p<$ 0.001 ) between the BOP-positive and -negative teeth. A multiple linear regression analysis showed that

\footnotetext{
連絡先: 渡邊達夫

干 700-8525 岡山市鹿田町 2-5-1 岡山大学大学院医歯学総合研究科口腔保健学分野

Tatsuo Watanabe

Department of Oral Health, Okayama University Graduate School of Medicine and Dentistry

2-5-1, Shikata-cho, Okayama 700-8525, Japan

E-mail wyobou@md.okayama-u.ac.jp
} 
AL had a stronger effect on degrees of tooth mobility than PD. These results indicate that PD and AL reflect the activity and severity of periodontal disease, respectively. Periodontal condition in maintenance patients should be evaluated based on the individual two aspects, activity (PD) and severity (AL) of periodontitis. J Jpn Soc Periodontol, 46 : 253-258, 2004.

Key words : periodontitis, probing depth, attachment level

要旨：プロービングデプスとアタッチメントレベルは, 臨床指標としてよく用いられる。本研究では, メイン テナンスに移行した歯周病患者における，プロービングデプスとアタッチメントレベル計測の臨床的な意義を検 討した。メインテナンス期にある 193 名の歯周病患者（平均年齢； 61.7 歳, 男性 77 名, 女性 116 名）を対象に した。プロービングデプスとアタッチメントレベルを，1歯 6 点法で計測し，年齢，性別，プロービング時出血 および動摇の有無との関連を評価した。1 人あたりの平均プロービングデプスとアタッチメントレベルは，それ ぞれ $1.89 \mathrm{~mm}$ と $2.75 \mathrm{~mm}$ であった。アタッチメントレベルでは年齢との相関（ $\mathrm{r}=0.36, p<0.001)$ が認めら れたが，プロービングデプスと年齢の間には，相関はなかった。また，出血のある部位のプロービングデプスと アタッチメントレベルの平均值は, 出血のない部位よりもそれぞれ大きな值となった $(p<0.001)$ 。さらに, 重 回帰分析から，歯の動摇度に対するアタッチメントレベルの影響力が，プロービングデプスより大きいことも示 された。これらの結果は, プロービングデプスは歯周病の活動性を, アタッチメントレベルは歯周病の重症度を 示す指標であることを示唆している。歯周状態の把握は, 活動性と重症度の両面から考慮されるべきなので, プ ロービングデプスとアタッチメントレベル双方の測定がメインテナンス時に不可欠である。

索引用語：歯周病, プロービングデプス, アタッチメントレベル

\section{緒言}

歯科医師や歯科衛生士による口腔の定期的なメイン テナンスは, 歯周組織の健康を維持させるのに重要で ある ${ }^{1-5)}$ 。歯周病患者が来院したとき，歯周組織の状 態を定量する指標として，プロービングデプスとア タッチメントレベルが広く用いられている ${ }^{6-9)}$ 。プ ロービングデプスは, 辺縁歯肉から歯周ポケット底部 までの距離を示し10), アタッチメントレベルはセメン ト・エナメル境から歯周ポケット底部までの長さを表 す11)。このように，これら 2 つの指標の違いは明らか であり, メインテナンス時において，プロービングデ プスとアタッチメントレベルの測定結果の臨床的意義 を検討することは，興味深いことである。

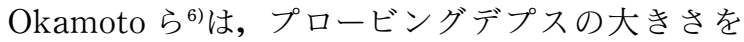
部位別にみたとき, 近・遠心部が中央部よりも大きい ことを報告した。南ら ${ }^{12)}$ は, 歯周処置後のプロービン グデプスの減少量について, 歯種や部位による差がな いことを示した。また石川 $\left.{ }^{13}\right)$ は，アタッチメントレベ ルについて, 最大部位の出現頻度が歯種で異なり, 部 位別には一定の傾向がないことを明らかにした。これ らに示される, プロービングデプスとアタッチメント レベルの特性は，それぞれの指標の役割を理解するた めの情報源となる。本研究では, メインテナンスに移 行した歯周病患者を対象に, プロービングデプスとア
タッチメントレベルの分布を性別，部位別，年齢別に 調べた。さらにプロービング時出血の有無, 歯の動摇 度との関連を評価し，それぞれの指標の臨床的意義を 比較した。

\section{対象および方法}

\section{1. 対 象}

岡山大学医学部 - 歯学部附属病院予防歯科外来患者 のうち, 歯周病のメインテナンス期にある患者 193 名 を対象とした。メインテナンス期の患者とは，3カ月 以上のリコール間隔で本院を継続的に受診しており, 半年以上歯肉・歯周膿慯などがみられず，歯周組織が 安定している者とした。

\section{2. 診査内容}

智歯を除く残存歯全て $(4,467$ 歯，26,802 部位）を 対象に, 動摇の程度, プロービングデプス, アタッチ メントレベル，プロービング時の出血の有無につい て, 歯科医師が事前にキャリブレーションを行い評価 した。プロービングデプスとアタッチメントレベル は，ヒューフレディ社製カラーコードプローブ （CP-11）を用いて1歯 6 点法で計測した。出血の有 無は, プロービング 30 秒後に確認した。動摇の有無 は, 歯に臨床的動摇（上血天科でキャリブレーション した後，ピンセットを用いて $150 \mathrm{~g}$ の力で動く）がみ られるかどうかで判断した ${ }^{14)} 。 150 \mathrm{~g}$ の力で動く歯を 
表 1 性別によるプロービングデプスとアタッチメントレベルの值の違い (平均值士標準偏差)

\begin{tabular}{|c|c|c|c|c|c|}
\hline & & 男性 & & 女性 & 全体 \\
\hline 対象者数 & （人） & 77 & & 116 & 193 \\
\hline 平均年齢 & （歳） & $62.3 \pm 9.8$ & & $61.2 \pm 11.2$ & $61.7 \pm 10.7$ \\
\hline 現在歯数 & （歯） & $22.6 \pm 5.9$ & & $23.5 \pm 5.5$ & $23.1 \pm 5.7$ \\
\hline プロービングデプス & $(\mathrm{mm})$ & $1.98 \pm 0.36$ & $* * *$ & $1.82 \pm 0.32$ & $1.89 \pm 0.35$ \\
\hline アタッチメントレベル & $(\mathrm{mm})$ & $3.04 \pm 0.93$ & $* * *$ & $2.55 \pm 0.88$ & $2.75 \pm 0.93$ \\
\hline
\end{tabular}

動摇度 $1,100 \mathrm{~g}$ の力で動く歯を動摇度 2 , そして 50 $\mathrm{g}$ の力で動く歯を動摇度 3 と規定した。なお，動摇の みられない歯は, 動摇度 0 とした。

\section{3. 分析方法}

各群の差の検定には, Mann-Whitney の $U$ 検定を 用いた。変数間の相関関係の分析では Spearman の 順位相関係数を求めた。また，プロービングデプスと アタッチメントレベルのプロービング時出血と歯の動 摇への影響力を比較するため, 強制投入法による重回 帰分析を行った。分析にはSPSS (10.0 J for Windows，エス・ピー・エス・エス株式会社，東京）を 用いた。

\section{結 果}

1. プロービングデプスとアタッチメントレベルの 男女別の平均值

性差による対象者の分布を比較した（表 1 ）。平均 年齢は男性 62.3 歳, 女性 61.2 歳で, 有意な差はな かった。また, 現在歯数も男性 22.6 歯, 女性 23.5 歯 で有意な差はなかった。しかし，プロービングデプ ス，アタッチメントレベルの平均值は，いずれも男性 の方が女性よりも大きな值を示した（ $p<0.001 ） 。$

2. プロービングデプス, アタッチメントレベルの 部位別の平均値

プロービングデプス, アタッチメントレベルの部位 別の平均值を図 1 に示した。上顎煩側，下顎煩側抢よ び下顎舌側に扔いて, アタッチメントレベルはプロー ビングデプスよりも大きな值を示した。特に，上顎煩 側臼歯部と下顎煩側のプロービングデプスとアタッチ メントレベルの差（いわゆる歯肉退縮の幅）が大き かった。また，プロービングデプスは中央部に比べ 近・遠心で大きかったが，アタッチメントレベルでは そのような一定の傾向は認められなかった。
3. プロービングデプス, アタッチメントレベルの 年齢との相関関係

アタッチメントレベルは，年齢と有意な正の相関を 示した $(\mathrm{r}=0.36, p<0.001)$ (図 2)。一方, プロー ビングデプスでは，年齢との正の相関が認められず, むしろ負の相関を示した $(\mathrm{r}=-0.17)$ 。

4. プロービング時出血の有無によるプロービング デプス, アタッチメントレベルの比較

全対象部位（26,802 部位）を，プロービング時に 出血を認めた部位と認められなかった部位に分類し た。この 2 群で年齢と性別をマッチングし, それぞれ 1,258 部位を抽出した。出血のある部位のプロービン グデプスとアタッチメントレベルの平均值は, 出血の ない部位よりもそれぞれ大きな值を示した（ 0.001)（図 3)。

また, プロービング時出血の有無を従属変数 $(0$ も しくは 1), プロービングデプスとアタッチメントレ ベルを説明変数として重回帰分析を行った。その結 果, プロービングデプスとアタッチメントレベルの標 準偏回帰係数の大きさは, それぞれ 0.167 と 0.011 で あった（表2）。

5. 歯の動摇に対するプロービングデプス, アタッ チメントレベルの影響力の比較

4,467 歯のうち，年齢，性別をマッチングした 460 歯を分析対象とした。動摇度 $0,1,2,3$ に相当する 歯は, それぞれ 227 歯, 183 歯, 37 歯, 13 歯あった。 動摇度の大きさを従属変数, プロービングデプスと アタッチメントレベルを説明変数として重回帰分析を 行ったところ, プロービングデプスとアタッチメント レベルの標準偏回帰係数は, それぞれ 0.162 と 0.319 そなった（表 3)。

\section{考 察}

アタッチメントレベルは，年齢と正の相関が認めら れ, さらに重回帰分析より歯の動摇度に大きな影響力 


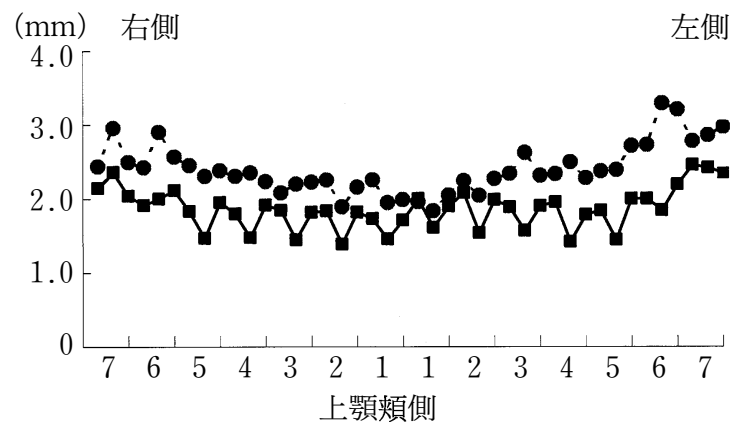

(mm) 右側 左側

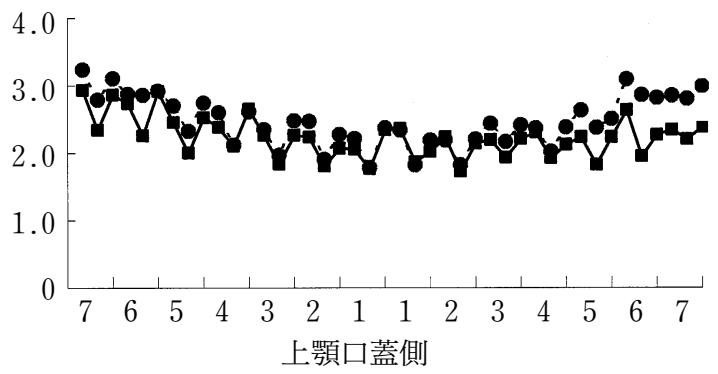

(mm) 右側

左側

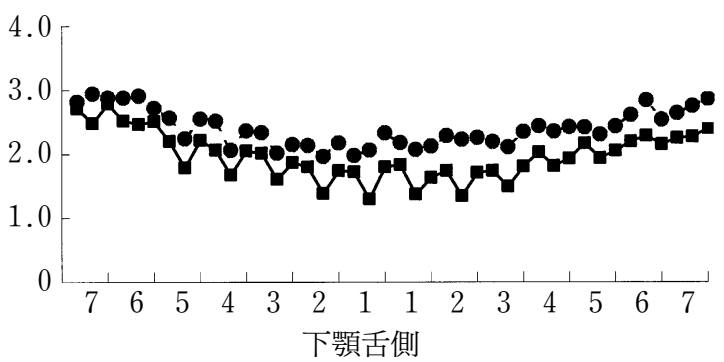

(mm) 右側

左側

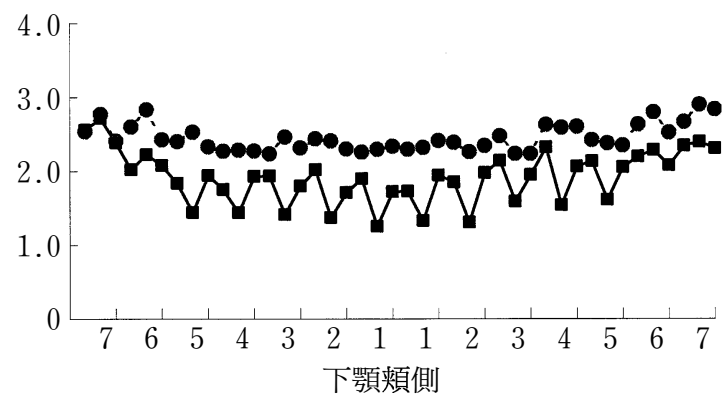

図 1 部位別のプロービングデプス（PD）と

$$
\text { アタッチメントレベル }(\mathrm{AL}) \text { の平均值 }
$$

.•. AL - - $\mathrm{AD}$

上から順に，上顎頓側，上顎口蓋側，下顎舌側，下 顎煩側の值を示す。上顎煩側, 下顎舌側及び下顎煩側 において, AL はPDよりも大きな值であった。特 に, 上顎煩側臼歯部と下顎煩側で差が大きかった。

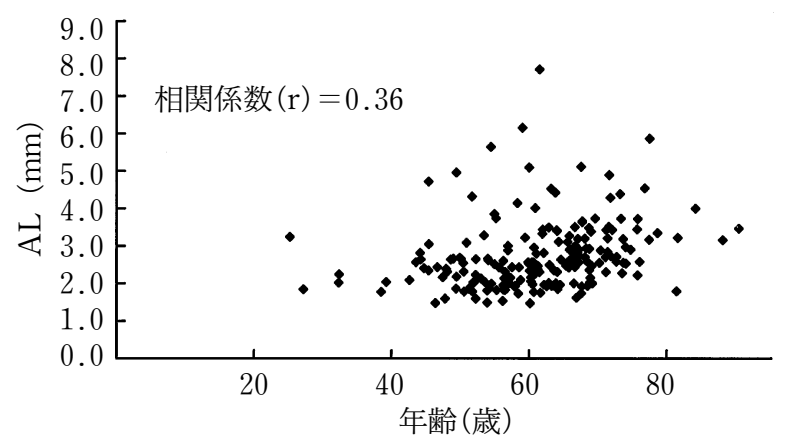

図 2 対象者の年歯とアタッチメントレベル (AL) の相関関係

年齢の増加に伴い, AL の值が大きくなるという相 関関係が認められる。

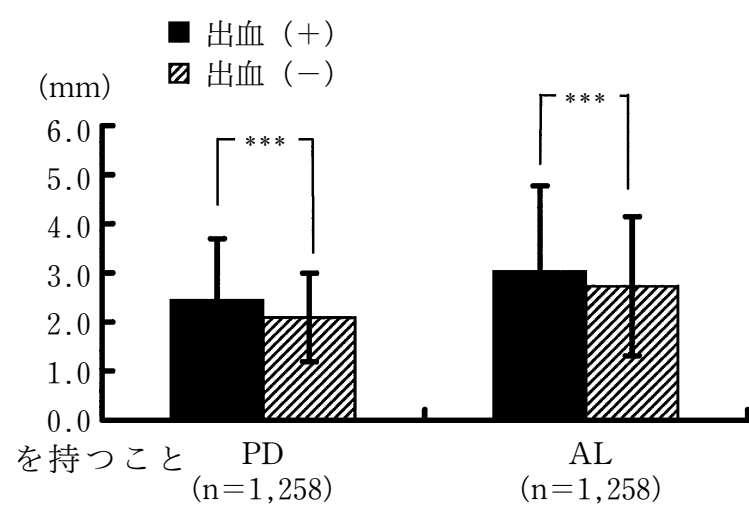

図 3 プロービング時出血の有無によるプロービング デプス（PD）とアタッチメントレベル（AL) の平均値の比較

$$
* * * p<0.001
$$

プロービング時出血のある部位の $\mathrm{PD}$ と $\mathrm{AL}$ の平均 值は, 出血のない部位よりも, それぞれ大きかった。

表 2 プロービング時出血の有無に対するプロービング デプスとアタッチメントレベルの影響力の比較

標準偏回帰係数 $(\beta)$ 相関係数 $(r)$

\begin{tabular}{lll}
\hline プロービングデプス & $0.167^{* * *}$ & $0.157^{* *}$ \\
アタッチメントレベル & 0.011 & $0.082^{* *}$ \\
\hline 重相関係数 $(R)$ & $0.160^{* * *}$ & \\
\hline $\mathrm{n}=2,516$ & & \\
$* * p<0.01, \quad * * * p<0.001$ & &
\end{tabular}


表 3 歯の動摇の大きさに対するプロービングデプスと アタッチメントレベルの影響力の比較

\begin{tabular}{llc}
\hline & \multicolumn{2}{c}{ 標準偏回㷌係数 $(\beta)$ 相関係数 $(\mathrm{r})$} \\
\hline プロービングデプス & $0.162^{* * *}$ & $0.317^{* * *}$ \\
アタッチメントレベル & $0.319^{* *}$ & $0.397^{* * *}$ \\
\hline 重相関係数 $(R)$ & $0.422^{* * *}$ & \\
\hline $\mathrm{n}=460$ & \\
$* * p<0.01, * * * p<0.001$ &
\end{tabular}

が示された。歯周病は, 加齢と共に増悪する ${ }^{15,16) 。 ま ~}$ た, 動摇の程度から歯周病の進行度を推測して, 抜歯 の判断基準とすることも日常経験する。これらは, ア タッチメントレベルが, 歯周病の進行の程度を反映す る, いわゆる重症度を表す指標であることを示唆して いる。

一方，プロービングデプスは，年齢と相関を示さな かった。また, 歯の動摇度への影響力もアタッチメン トレベルより小さかったことから, 重症度との関連は 低い。しかし, プロービング時の出血の有無について は, プロービングデプスはアタッチメントレベルより も大きな影響力を示した。プロービング時の出血は, 歯周病の活動性の大きさを反映するという ${ }^{17,18)}$ 。以上 のことから, プロービングデプスは, 歯周病の重症度 を表すと考えるより，むしろ活動性を表す指標として 適していると思われる。

プロービングデプスとアタッチメントレベルは異 なった特性を示した。このことは，それぞれの指標の 持つ意味を独立して考える必要があることを示唆して いる。歯周病は, 静止期と活動期を繰り返す疾患であ り，歯周組織の破壊は活動期の蓄積として現れる ${ }^{19)}$ 。 それゆえに, 歯周状態は, 静止期と活動期のいずれの 段階であるのかを示すプロービングデプスと歯周病に よる組織破壊の程度を示すアタッチメントレベルの両 面から検討されることが妥当である。

歯周病が活動性を高め, 組織破壊が進行したとき, 結果としてアタッチメントロスが生じる7)。Haffajee $ら^{20)}$ は，プロービングデプス，プロービング時の出 血, および歯垢指数などからその後のアタッチメント ロスの予測可能性を, 敏感度, 特異度を求めることに より評価した。Halazonetis ら ${ }^{21)}$ は, アタッチメント ロスの変化量を 3 つのカテゴリーに分けて，それぞれ の場合について，プロービングデプスなどの臨床指標 がどの程度寄与しているのか追跡した。しかし，いず れもアタッチメントロスをプロービングデプスから予 測することが出来ていない。これらは, 歯周病の重症 度の変化を, 歯周病の活動性から推測することが困難
であることを示唆している。すなわち, 歯周病の活動 性と重症度は, それぞれ個別に評価される必要があ る。

メインテナンス時において, 歯周病の重症度は, そ の歯の寿命があとどれくらいなのかを予測する情報源 となる ${ }^{22)}$ 。また, 歯周病の活動性の大きいことは, 炎 症に対して何らかの処置が現在必要であることを意味 する。本研究は, プロービングデプスとアタッチメン トレベルをそれぞれ歯周病の活動性と重症度を示す指 標と捉えることで, 歯周組織をメインテナンスするの に，より適切な診断と治療方針の決定ができることを 支持している。

本研究では, プロービング時出血との関連性が高い ことから, プロービングデプスを歯周病の活動性を表 すのに適した指標として考えた。しかし実際には，プ ロービングデプスが大きくてもプロービング時出血が みられず, 歯周病の活動性が低いと判断される場合が ある。したがって, 歯周病の活動性の判断には, プ ロービングデプスの大きさだけではなくプロービング 時出血の有無も考慮した評価が大切である。

結論として，プロービングデプスとアタッチメント レベルは, それぞれ歯周病の活動性と重症度を示す指 標であると考えられる。そして, 歯周状態の把握に は, 活動性と重症度の両面から考慮される必要があ り，そのためには，プロービングデプスとアタッチメ ントレベル双方の測定が不可欠である。

本論文の要旨は, 第 43 回秋季日本歯周病学会学術大会 （2000 年 10 月 20 日）において発表した。

\section{文献}

1) Axelsson $P$, Lindhe $J$ : The significance of maintenance care in the treatment of periodontal disease. J Clin Periodontol, 8 : 281-294, 1981.

2) Becker W, Berg L, Becker BE: The long term evaluation of periodontal treatment and maintenance in 95 patients. Int J Periodontics Restorative Dent, $4: 54-71,1984$

3) Lindhe J, Nyman S : Long-term maintenance of patients treated for advanced periodontal disease. J Clin Periodontol, 11 : 504-514, 1984.

4) Ramfjord SP : Maintenance care and supportive periodontal therapy. Quintessence Int, 24:465471, 1993.

5) Rosen B, Olavi G, Badersten A, Ronstrom A, Soderholm G, Egelberg J : Effects of different frequencies of preventive maintenance treatment on periodontal conditions. Five-year observations 
in general dentistry patients. J Clin Periodontol, $26: 225-233,1999$.

6) Okamoto H, Yoneyama T, Lindhe J, Haffajee A, Socransky S: Methods of evaluating periodontal disease data in epidemiological research. J Clin Periodontol, 15 : 430-439, 1988.

7) Haffajee $\mathrm{AD}$, Socransky SS, Lindhe J, Kent RL, Okamoto $\mathrm{H}$, Yoneyama $\mathrm{T}$ : Clinical risk indicators for periodontal attachment loss. J Clin Periodontol, $18: 117-125,1991$.

8) Papapanou PN, Lindhe J, Sterrett JD, Eneroth $\mathrm{L}$ : Considerations on the contribution of aging to loss of periodontal tissue support. J Clin Periodontol, 18:611-615, 1991.

9) Baelum V, Luan WM, Chen X, Fejerskov O : A 10-year of the progression of destructive periodontal disease in adult and elderly Chinese. J Periodontol, 68: 1033-1042, 1997.

10) Listgarten MA : Periodontal probing: What does it mean? J Clin Periodontol, $7: 165-176,1980$.

11) Lindhe $\mathrm{J}:$ Textbook of clinical periodontology. Munksgaard, Copenhagen, 302, 1985.

12）南 睦美，長野恭子，瀬戸康博，和泉雄一，末田 武：歯肉剥離搔爬術後のプロービングデプスの変化 に関する研究 歯種や部位による相違について。 日 歯周誌, $35 ： 518-523,1993$

13）石川 昭：抜去歯を用いたアタッチメント・ロスの 疫学的研究. 岡山歯誌, 9:123-137, 1990.

14）渡邊達夫，森田 学，平岩 弘，岸本悦夫：歯口清
掃による動摇歯の改善と宿主因子の関係. 口腔衛生 会誌, 34：220-225, 1984.

15) Mumghamba EG, Markkanen HA, Honkala E : Risk factors for periodontal diseases in Ilala, Tanzania. J Clin Periodontol, 22 : 347-354, 1995.

16) Page RC, Beck JD: Risk assessment for periodontal diseases. Int Dent J, 47 : 61-87, 1997.

17) Greenstein $G$ : The role of bleeding upon probing in the diagnosis of periodontal disease. A literature review. J Periodontol, 55:684-688, 1984.

18) Lang NP, Adler R, Joss A, Nyman S : Absence of bleeding on probing. An indicator of periodontal stability. J Clin Periodontol, 17 : 714-721, 1990.

19) Socransky SS, Haffajee AD, Goodson JM, Lindhe $\mathrm{J}$ : New concepts of destructive periodontal disease. J Clin Periodontol, 11 : 21-32, 1984.

20) Haffajee AD, Socransky SS, Goodson JM : Clinical parameters as predictors of destructive periodontal disease activity. J Clin Periodontol, 10 : 257-265, 1983.

21) Halazonetis TD, Haffajee AD, Socransky SS : Relationship of clinical parameters to attachment loss in subjects with destructive periodontal disease. J Clin Periodontol, 16 : 563-568, 1989.

22）山本龍生，渡邊達夫，滝沢秀彦，梅村長生：8020 達成予測は可能か「有効歯根表面積」を用いた歯 の残存予測法の開発. 日本歯科医師会誌, 56：415423, 2003. 